\title{
Studies on cambial activity: advances and challenges in the knowledge of growth dynamics of Brazilian woody species
}

\author{
CÁTIA H. CALLADO ${ }^{1,2}$, THAÍS J. DE VASCONCELLOS ${ }^{2}$, MONIQUE S. COSTA ${ }^{2}$, \\ CLAUDIA F. BARROS ${ }^{3}$, FIDEL A. ROIG $^{4}$ and MÁRIO TOMAZELLO-FILHO ${ }^{5}$ \\ ${ }^{1}$ Universidade do Estado do Rio de Janeiro, Laboratório de Anatomia Vegetal, Instituto de Biologia Roberto Alcantara Gomes, \\ Rua São Francisco Xavier, 524 - PHLC, sala 224, 20550-013 Rio de Janeiro, RJ, Brasil \\ ${ }^{2}$ Programa de Pós-Graduação em Biologia Vegetal, Universidade do Estado do Rio de Janeiro, Instituto de Biologia Roberto \\ Alcantara Gomes, Rua São Francisco Xavier, 524 - PHLC, sala 224, 20550-013 Rio de Janeiro, RJ, Brasil \\ ${ }^{3}$ Instituto de Pesquisas Jardim Botânico do Rio de Janeiro, Botânica Estrutural, \\ Rua Pacheco Leão, 915, 22460-030 Rio de Janeiro, RJ, Brasil \\ ${ }^{4}$ Laboratorio de Dendrocronología e Historia Ambiental, Instituto Argentino de Nivología, \\ Glaciología y Ciencias Ambientales, Centro Científico Tecnológico CONICET-Mendoza, \\ Av. Ruiz Leal, s/n, Parque Gral. San Martín, CC 330, 5500 Mendoza, Argentina \\ ${ }^{5}$ Departamento de Ciências Florestais, Escola Superior de Agricultura Luis de Queiroz, \\ Universidade de São Paulo, Av. Pádua Dias, 11, Caixa Postal 09, 13418-900 Piracicaba, SP, Brasil
}

Manuscript received on January 29, 2013; accepted for publication on April 24, 2013

\begin{abstract}
The lack of specific research on the sequence of events that determine plant growth from meristem until wood formation represents a gap in the knowledge of growth dynamics in woody species. In this work, we surveyed published studies concerning cambial activity of Brazilian native species aiming at allowing the comparison of applied methods and obtained results. The annual cambial seasonality was observed in all the investigated species. Nevertheless, we found high heterogeneity in the used methodologies. As a result from this analysis, our opinion points to the need for standardizing sampling protocols and for discussing the suitability of experimental designs. This will help to define with greater precision the factors that determine the radial growth in the different tropical ecosystems.
\end{abstract}

Key words: wood formation, growth rings, radial growth, dendrochronology.

\section{INTRODUCTION}

The dendrochronology is the study of the growth rings of woody species (Figs. 1A-1B) and is the main form of analysis of age and diameter increment rates of these species. The analysis of the role of biotic and abiotic factors in ring formation provides the knowledge of radial growth dynamics, within a space of time that goes from weeks to millennia, reflecting directly the periodicity of cambial activity.

Correspondence to: Cátia Henriques Callado

E-mail: ccallado@uerj.br
Although cell division and elongation are the main processes related to plant growth, these two processes are not frequently considered in studies of radial growth. The lack of this type of analysis produces a gap in the understanding of the sequence of events from the cellular level and to the increment in diameter, shown in annual ring width (Fig. 1). Thus, environmental variables identified as controllers of the growth in dendrocronological analyses might not be necessarily, the variables that trigger the beginning and the duration of cambial activity (Köcher et al. 2012). 

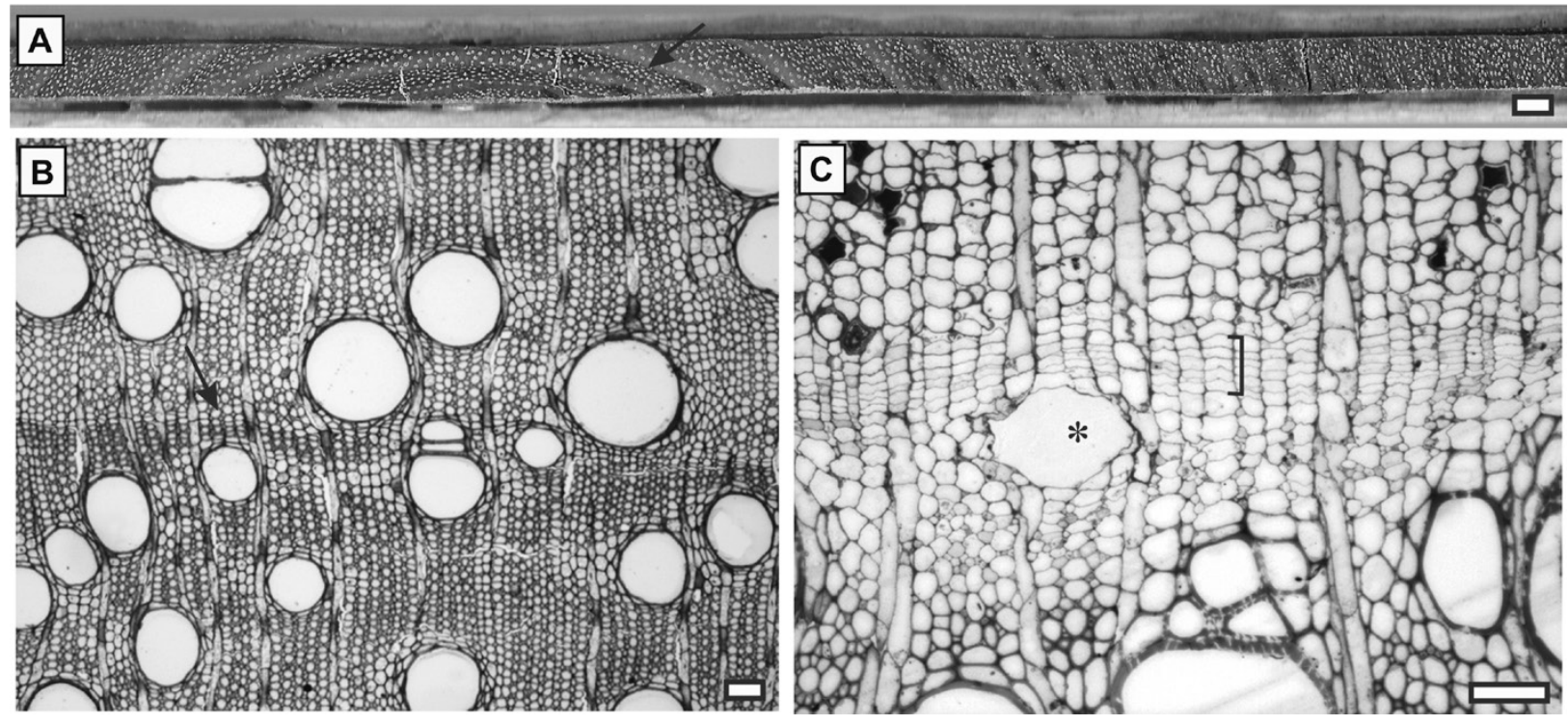

Figure 1 - Growth rings in Centrolobium robustum (Vell.) Mart. ex Benth. (Fabaceae). A: Macroscopical observation in transverse section of wood - note growth rings (arrow) and their variation in width. B: Anatomical observation of wood - note the boundary between two adjacent growth rings (arrow). C: Anatomical observation of a growth ring formation - note cambial zone in the active period (bracket) and a differentiating vessel element (asterisk). Scale bars: $\mathrm{A}=1 \mathrm{~mm}$; and $\mathrm{B}, \mathrm{C}=50 \mu \mathrm{m}$.

The knowledge about the duration of cambial activity is fundamental in these studies, since it is in this time that trees receive and store the stimuli that are directly responsible for their growth (Frankenstein et al. 2005). The duration of activity of the cambium is also relevant in determining the quantity/quality of wood and in the comprehension of the adaptation of woody species to different environments (Begum et al. 2007, 2012). However, this relationship remains as an intriguing question and not completely understood (Lupi et al. 2010), especially for tropical woody species.

In this study, we review the papers dealing with cambial activity, with reference to Brazilian species and put them in context regarding their advances and challenges in the knowledge of this aspect of tropical biodiversity.

\section{CAmbial ACtivity: AdVANCES IN THE KNOWLEDGE OF THE GROWTH DYNAMICS OF BRAZILIAN WOODY SPECIES}

In Brazil, only eight studies dealing with cambial activity of native woody species were published until to date: Silva et al. (1991), Dünisch et al. (2002,
2003), Marcati and Angyalossy (2005), Marcati et al. (2006, 2008), Callado (2010) and Lima et al. (2010). These studies were carried out in different ecofloristics zones (Table I) of two important biomes: Atlantic Rain Forest and Amazon Forest.

From these papers, only two combined dendrochronological approaches with histological analysis of the cambial activity (Dünisch et al. 2002, 2003). The paper of Lima et al. (2010) was the only one in which the growth of a liana was investigated (Table I).

The number of sampled plants for histological analysis of the cambial zone varied from 1 to 12 individuals per species (Table I), while the height of sampling was always performed at $1.30 \mathrm{~m}$ from the ground, even in the liana Tynanthus cognatus analyzed by Lima et al. (2010). The observation frequency established in the studies varied considerably, ranging from a monthly frequency to sampling exclusively during the dormancy period (Table II).

The cambial seasonality, which determines annual growth rings formation, was confirmed in all the studies. The existence of a period of water deficit occurred in four of the seven study sites 
TABLE I

Studied species and physiognomies, habit of the species, number of sampled individuals per species $(\mathrm{N})$, and reference to the published papers.

\begin{tabular}{|c|c|c|c|c|}
\hline Species & Physiognomies & Habit & $\mathbf{N}$ & Published papers \\
\hline \multicolumn{5}{|l|}{ Bignoniaceae } \\
\hline Tynanthus cognatus Miers & Seasonal Semidecidual Forest & Lianescent & * & Lima et al. 2010 \\
\hline \multicolumn{5}{|l|}{ Fabaceae } \\
\hline Schizolobium parahyba (Vell.) Blake & Seasonal Semidecidual Forest & Arboreous & 3 & Marcati et al. 2008 \\
\hline \multicolumn{5}{|l|}{ Lecythidaceae } \\
\hline Cariniana estrellensis (Raddi) Kuntze & Atlantic Rain Forest & Arboreous & 5 & Callado 2010 \\
\hline \multicolumn{5}{|l|}{ Meliaceae } \\
\hline Carapa guianensis Aubl. & $\begin{array}{l}\text { Amazon Forest and } \\
\text { cultivated in native area }\end{array}$ & Arboreous & 12 & Dünisch et al. 2002 \\
\hline Cedrela fissilis Vell. & Seasonal Semidecidual Forest & Arboreous & 2 & Marcati et al. 2006 \\
\hline Cedrela odorata L. & $\begin{array}{l}\text { Amazon Forest } \\
\text { cultivated in native area }^{(1)} \text { and }\end{array}$ & Arboreous & $12^{(1)}$ & $\begin{array}{l}\text { Dünisch et al. } 2002^{(1)}, \\
2003^{(2)} \text {, Silva et al. } 1991^{(3)}\end{array}$ \\
\hline Swietenia macrophylla King. & $\begin{array}{l}\text { Amazon Forest } \\
\text { in native }{ }^{(1)} \text { and } \text { urban }^{(3)} \text { area }\end{array}$ & Arboreous & $\begin{array}{c}12^{(1)}, \\
1^{(3)}\end{array}$ & $\begin{array}{l}\text { Dünisch et al. } 2002^{(1)}, \\
2003^{(2)} \text {, Silva et al. } 1991^{(3)}\end{array}$ \\
\hline \multicolumn{5}{|l|}{ Verbenaceae } \\
\hline Citharexylum myrianthum Cham. & Seasonal Semidecidual Forest & Arboreous & 4 & $\begin{array}{l}\text { Marcati and Angyalossy } \\
\qquad 2005\end{array}$ \\
\hline
\end{tabular}

* Data not available.

TABLE II

Studied species, leaf phenological behavior, observation frequency of the cambial activity (Sampling), beginning of the cambial activity $(\mathrm{BC})$, type of marginal parenchyma $(\mathrm{P})$, and reference to the published papers.

\begin{tabular}{|c|c|c|c|c|c|}
\hline Species & Leaf phenology & Sampling & BC & $\mathbf{P}$ & Published papers \\
\hline \multicolumn{6}{|l|}{ Bignoniaceae } \\
\hline $\begin{array}{l}\text { Tynanthus } \\
\text { cognatus }\end{array}$ & $*$ & \pm Monthly & $\begin{array}{c}\text { March (VC) } \\
\text { and April (RC) }\end{array}$ & Initial & Lima et al. 2010 \\
\hline \multicolumn{6}{|l|}{ Fabaceae } \\
\hline $\begin{array}{l}\text { Schizolobium } \\
\text { parahyba }\end{array}$ & Decidual & \pm Bimonthly & August & Initial & Marcati et al. 2008 \\
\hline \multicolumn{6}{|l|}{ Lecythidaceae } \\
\hline $\begin{array}{l}\text { Cariniana } \\
\text { estrellensis }\end{array}$ & Semidecidual $^{(a)}$ & $\begin{array}{l}\text { Activity and } \\
\text { dormancy }\end{array}$ & $*$ & $\begin{array}{l}\text { Without marginal } \\
\text { parenchyma }\end{array}$ & Callado 2010 \\
\hline \multicolumn{6}{|l|}{ Meliaceae } \\
\hline $\begin{array}{l}\text { Carapa } \\
\text { guianensis }\end{array}$ & Evergreen $^{(\mathrm{b})}$ & Monthly & December & Terminal & Dünisch et al. 2002 \\
\hline Cedrela fissilis & $\begin{array}{l}\text { Semidecidual } \\
\text { to decidual }\end{array}$ & $\begin{array}{l}\text { Activity and } \\
\text { dormancy }\end{array}$ & $*$ & $\begin{array}{l}\text { Initial and } \\
\text { terminal }\end{array}$ & Marcati et al. 2006 \\
\hline Cedrela odorata & Decidual $^{(\mathrm{b})}$ & $\begin{array}{l}\text { Monthly }{ }^{(1)} \text {; } \\
\text { dormancy }^{(2)}\end{array}$ & December $^{(1)}$ & Initial $^{(1)}$ & $\begin{array}{l}\text { Dünisch et al. } 2002^{(1)} \\
2003^{(2)}, \text { Silva et al. } 1991^{(3)}\end{array}$ \\
\hline $\begin{array}{l}\text { Swietenia } \\
\text { macrophylla }\end{array}$ & Semidecidual $^{(\mathrm{b})}$ & $\begin{array}{l}\text { Monthly }^{(1,3)} \\
\text { dormancy }^{(2)}\end{array}$ & December $^{(1,3)}$ & Terminal $^{(1)}$ & $\begin{array}{c}\text { Dünisch et al. } 2002^{(1)} \\
2003^{(2)}, \text { Silva et al. } 1991^{(3)}\end{array}$ \\
\hline \multicolumn{6}{|l|}{ Verbenaceae } \\
\hline $\begin{array}{l}\text { Citharexylum } \\
\text { myrianthum }\end{array}$ & Decidual $^{(\mathrm{c})}$ & $\begin{array}{l}\text { Activity and } \\
\text { dormancy }\end{array}$ & $*$ & $*$ & Marcati and Angyalossy 2005 \\
\hline
\end{tabular}

Additional references: (a) Lisi et al. 2008; (b) Dünisch and Moraes (2002); (c) Callado et al. 2001. VC: Variant cambium. RC = Regular cambium.

* Data not observed. \pm Approximate time. 
(Figs. 2 B, C, D and F). However, the existence of at least 2 months of precipitation lower than $60 \mathrm{~mm}$ was observed in six of these areas (Figs. 2 B, C, D, E, F and $\mathrm{G})$. These observations corroborate the Worbes's prediction in which annual growth rings are formed in tropical areas under this climatic characteristic (Worbes 1995). However, at Manaus (Fig. 2 A), where precipitation rates were over $60 \mathrm{~mm}$ along the year (no dry season), Dünisch et al. (2002) showed that different tree species (Carapa guianensis, Cedrela odorata and Swietenia macrophylla) presented seasonality in the cambial activity with consequent formation of annual growth rings. Thus, we observe that in the three analyzed species the periodical rhythm is annual and independent of the existence of drought periods.
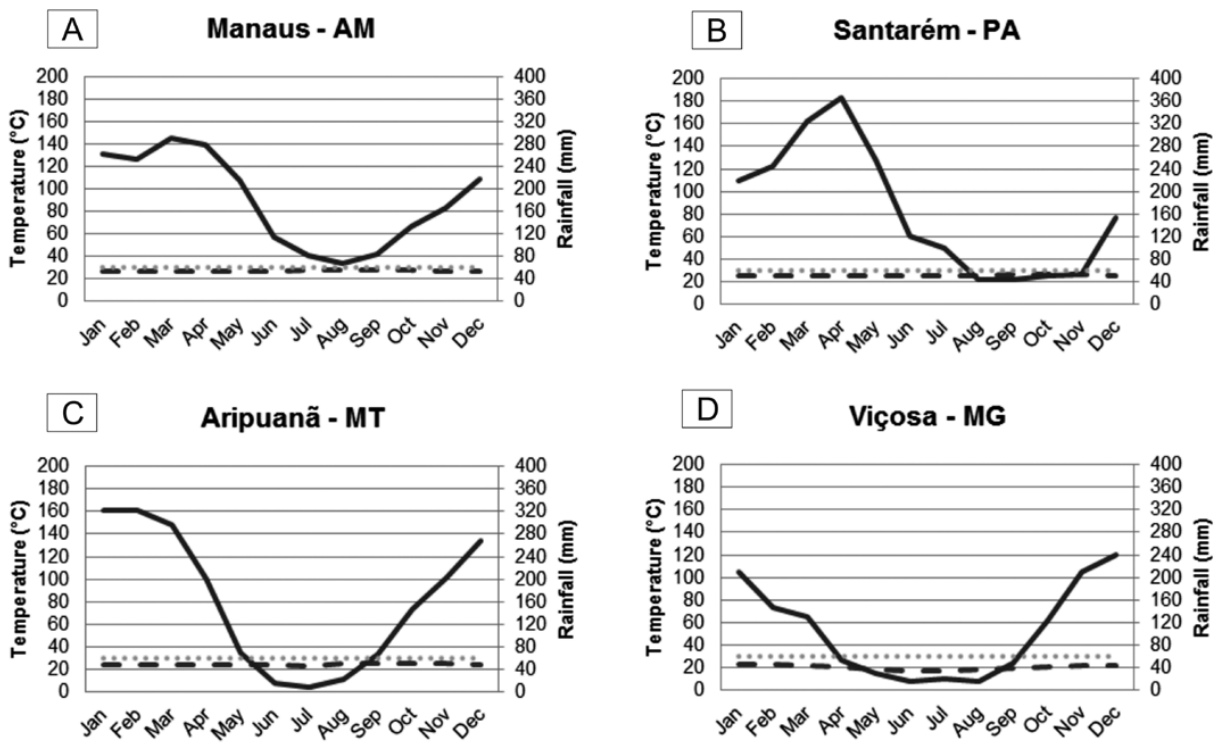

E Rio de Janeiro - RJ

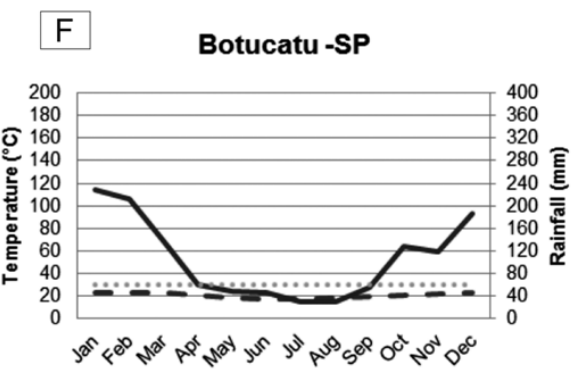

G São Paulo - SP
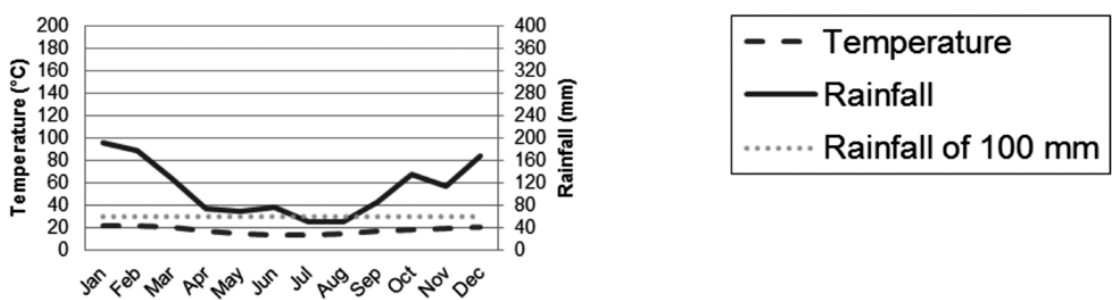

Figure 2 - Climatic diagrams of the seven study sites in which the studies of cambial activity were carried out (built from data obtained in DIVA Gis software Version 7.5). A: Manaus - AM. B: Santarém - PA. C: Aripuanã - MT. D: Viçosa - MG. E: Rio de Janeiro - RJ. F: Botucatu - SP. G: São Paulo - SP. 
The production of new cells, followed by cell elongation, was related to the increase of precipitation rates in seven of the studied species (Table II). Only in Tynanthus cognatus, the beginning of the cambial activity occurred at the end of the rainy season and the beginning of the dry season (Lima et al. 2010). This result is particularly contrasting not only in relation to the analyses in other studies, but also to what we know for other tropical woody species (e.g., Aljaro et al. 1972, Avila et al. 1975, Villalba 1985, Bräuning et al. 2009, Volland-Voigt et al. 2011, Giantomasi et al. 2012).

The formation of annual growth rings was observed even in deciduous, semideciduous and evergreen species (Table II). The vegetative and reproductive phenology was analyzed in three of the studies where were observed a relationship between foliar phenology and periods of cambial activity and dormancy in the following species: Cedrela fissilis (Marcati et al. 2006), Citharexylum myrianthum (Marcati and Angyalossy 2005) and Schizolobium parahyba (Marcati et al. 2008).

Dünisch et al. (2002) analyzed the influence of the attack of Hypsipyla grandella over the cambial activity, a fact that induces the formation of axial parenchyma bands and resin canals in Carapa guianensis, Cedrela odorata and Swietenia macrophylla. This parenchyma bands represent false growth rings, which difficult the dendrochronological dating processes. The study of Marcati and Angyalossy (2005) also added information to the physiological dynamics of radial growth of Citharexylum myrianthum, evidencing the relationship between cambial activity and the formation of calcium oxalate crystals. The authors associated the presence of crystals to the dormancy period and its degradation during the period of cambial activity.

In these studies, the results obtained did not allow to accurately determine the beginning and the end of the cambial activity. This is related especially to the frequency of sampling (Table II). However, it was possible to determine the period in which the marginal parenchyma bands were formed in the growth rings in six of the seven species that showed this characteristic (Table II). The characterization of marginal parenchyma as initial or terminal increases the accuracy of determining the limits of growth rings, thus, increasing the confidence of correlations with inductive or inhibiting factors of growth.

CAmbial ACtivity: CHALlEngES IN THE KNOWLEDGE OF THE GROWTH DYNAMICS OF BRAZILIAN WOODY SPECIES

The challenges to the study of cambial activity consist not only in the necessary increase of the number of studied species and phytophysiognomies, but also on the creation of a standard methodology and on broadness of the discussions of the obtained results.

It is necessary to define, for example, the sampling and the experimental design to be adopted. In this context, it is necessary to answer questions that still remain open, such as: (i) How many plants should be sampled per species?; (ii) How many points in the circumference should be sampled within the same plant?; (iii) What is the ideal sampling periodicity?; (iv) How long the experimental design should be?; (v) Which environmental and biological variables should be simultaneously monitored?; (vi) How to determine effectively the periods of cambial dormancy and activity?

The present results give an opportunity to open the discussions on: (i) how to determine more accurately the type, the frequency and the structural characteristics of the formed cells along the growth rings and thus confidently determine its boundaries and (ii) how to understand how inductive (favorable periods) or inhibiting (unfavorable periods) factors of the cambial activity determine the formation of different or similar cell types.

\section{ACKNOWLEDGMENTS}

We are grateful to the Conselho Nacional de Desenvolvimento Científico e Tecnológico (CNPq), the Fundação Carlos Chagas Filho de Amparo 
à Pesquisa do Rio de Janeiro (FAPERJ), and the Coordenação de Aperfeiçoamento de Pessoal de Nível Superior (CAPES) for their financial support. We thank Dr. G.U.C.A. dos Santos and V. Munson for helping with the English translation. This study was part of the inventory of the research about growth dynamic of South American species.

\section{RESUMO}

A escassez de pesquisas específicas sobre a sequência de eventos que determinam o crescimento das plantas, desde o meristema até a formação de madeira, representa uma lacuna no conhecimento sobre a dinâmica de crescimento de espécies lenhosas. Neste trabalho, foi realizado o levantamento dos estudos publicados sobre a atividade cambial de espécies nativas brasileiras com a finalidade de comparar a metodologia aplicada e os resultados obtidos. A sazonalidade anual do câmbio foi observada em todas as espécies investigadas. Todavia, foi observada uma alta heterogeneidade nas metodologias utilizadas. Como resultado desta análise, a nossa opinião aponta para a necessidade de padronizar os protocolos de amostragem e de discutir a adequação do delineamento experimental. Isso permitiria definir, com maior precisão, os fatores que determinam o crescimento radial em diferentes tipos de ecossistemas tropicais.

Palavras-chave: formação da madeira, anéis de crescimento, crescimento radial, dendrocronologia.

\section{REFERENCES}

Aljaro ME, Avila G, Hoffmann A AND Kummerow J. 1972 The annual rhythm of cambial activity in two woody species of the Chilean "matorral". Am J Bot 59: 879-885.

Avila G, Aljaro me, araya S, Montenegro G and KUMMEROW J. 1975. The seasonal cambium activity of Chilean and Californian shrubs. Am J Bot 62: 473-478.

Begum S, NAKaba S, ORIBE Y, KubO T AND FunAda R. 2007. Induction of cambial reactivation by localized heating in a deciduous hardwood hybrid poplar (Populus sieboldii $\times P$. grandidentata). Ann Bot 100: 439-447.

Begum S, Nakaba S, Yamagishi Y, ORIBE Y AND FunAda R. 2012. Regulation of cambial activity in relation to environmental conditions: understanding the role of temperature in wood formation of trees. Physiol Plantarum 147: 46-54.
BräUNING A, VOLland-VOIGT F, BURCHARDT I, GANZHI O, NAUSS T AND PETERS T. 2009. Climatic control of radial growth of Cedrela montana in a humid mountain rain forest in southern Ecuador. Erdkunde 63: 337-345.

CAllado CH. 2010. Os anéis de crescimento no estudo da dinâmica populacional na Floresta Atlântica. In: ABSY ML, MATOS FDA AND AMARAL IL (Eds), Diversidade Vegetal Brasileira: conhecimento, conservação e uso, Manaus: SBB, p. 227-231.

Callado CH, Silva Neto SJ, Scarano FR, Barros CF AND CostA CG. 2001. Anatomic features of growth rings in flood-prone trees of the Atlantic Rain Forest in Rio de Janeiro, Brazil. IAWA J 22: 29-42.

DÜNISCH O, BAUCH J AND GASPAROTTO L. 2002. Formation of increment zones and intraannual growth dynamics in the xylem of Swietenia macrophylla, Carapa guianensis, and Cedrela odorata (Meliaceae). IAWA J 23: 101-119.

DÜNISCH O, MonTÓIA VR AND BAUCH J. 2003. Dendroecological investigations on Swietenia macrophylla King and Cedrela odorata L. (Meliaceae) in the central Amazon. Trees 17: 244-250.

DÜNISCH O AND MORAES RR. 2002. Regulation of xylem sap flow in an evergreen, a semi-deciduous, and a deciduous Meliaceae species from the Amazon. Trees 16: 404-416.

Frankenstein C, EcKstein D And Schmitt U. 2005. The onset of cambium activity - A matter of agreement? Dendrochronologia 23: 57-62.

Giantomasi MA, ROIG-JuñEnt FA, PATÓN-DomíngueZ D AND MASSACCESI G. 2012. Environmental modulation of the seasonal cambial activity in Prosopis fexuosa DC trees from the Monte woodlands of Argentina. J Arid Environ 76: $17-22$.

KÖCHER P, HORNA V AND LEUSCHNER C. 2012. Environmental control of daily stem growth patterns in five temperate broad-leaved tree species. Tree Physiol 32: 1021-1032.

Lima AC, PACE MR And Angyalossy V. 2010. Seasonality and growth rings in lianas of Bignoniaceae. Trees 24: 1045-1060.

LiSI CS, TOMAZELLO-FILHO M, BOTOSSO PC, ROIG FA, MARIA VRB, FERREIRA-FEDELE L AND VOIGT ARA. 2008. TreeRing formation, radial increment periodicity, and phenology of tree species from a Seasonal Semi-Deciduous Forest in Southeast Brazil. IAWA J 29: 189-207.

Lupi C, Morin H, Deslauriers A AND Rossi S. 2010. Xylem phenology and wood production: resolving the chickenor-egg dilemma. Plant Cell Environ 33: 1721-1730.

MARCATI CR AND ANGYALOSSY V. 2005. Seasonal presence of acicular calcium oxalate crystals in the cambial zone of Citharexylum myrianthum (Verbenaceae). IAWA J 26: 93-98.

MARCATI CR, ANGYALOSSY V AND EVERT RF. 2006. Seasonal variation in wood formation of Cedrela fissilis (Meliaceae). IAWA J 27: 199-211.

Marcati CR, Milanez CRD AND Machado SR. 2008 Seasonal development of secondary xylem and phloem in Schizolobium parahyba (Vell.) Blake (Leguminosae: Caesalpinoidae). Trees 22: 3-12. 
Silva EAM, PEREIRA LAR, PINHEIRO AL AND RAMALHO RS. 1991. Variação sazonal na atividade cambial de três espécies florestais na região de Viçosa-MG. Revista Seiva 50: 49-52.

Villalba R. 1985. Xylem structure and cambial activity in Prosopis flexuosa DC. IAWA Bull 6: 119-130.
VOLLAND-VOIGT F, BRÄUNING A, GANZHI O, PETERS T AND MAZA H. 2011. Radial stem variations of Tabebuia chrysantha (Bignoniaceae) in different tropical forest ecosystems of southern Ecuador. Trees 25: 39-48.

WORBES M. 1995. How to measure growth dynamics in tropical trees - a review. IAWA J 16: 337-351. 